\title{
2 Insights from an assemblage perspective for a (better) understanding of energy transitions
}

\author{
Facing the challenge of sustainability in \\ Lebanon's energy crisis
}

\author{
Dana Abi Ghanem
}

\section{Introduction}

This chapter takes the case of the electricity infrastructure in Lebanon to demonstrate how assemblage as a theoretical perspective can be useful in advancing thinking on energy and sustainability transitions in cities of the global South. It builds on qualitative research conducted in Lebanon on the power outages that blight the everyday life of the country's denizens, delving into their history in the context of the civil war and the subsequent post-war developments that have shaped electricity services since. Whilst the example of Lebanon is not necessarily representative of the various challenges and priorities facing cities with regards to energy access and sustainability, the purpose here is to contribute an analytical lens that can advance our thinking and policy making on energy transitions in the global South.

In Lebanon, electricity services face a major crisis. The electricity generated is insufficient to meet demand (Bouri and El-Assad, 2016), resulting in unreliable services and scheduled power outages. This has become an endemic problem for the country's residents that began during the Lebanese civil war (1975-1990) and continues to this day (Abi Ghanem, 2018; Moore and Collins, 2020). Post-war reconstruction efforts since the early 1990s (World Bank, 1996) have led to a rise in living standards and consequently a rise in demand for electricity services. However, the energy sector is still hampered by corruption and mismanagement, whereby subsequent investment in the network infrastructure fails to fill the supply gap (Abdelnour, 2003). The corrupt practices also involve the national utility company - Électricité du Liban (EDL) - which has not been able to recoup monthly billing nor control illegal connections to the grid (Moore and Collins, 2020) and is in deficit (UN-ESCWA, 2017). With Lebanon relying heavily on imported fuel oil (OECF/IEA, 2014), the energy sector is responsible for a large part of the country's external debt (World Bank, 2019) and has become a financial burden on the country's economy.

Furthermore, recent developments in the region, namely the Syrian war that began in 2011 and is still ongoing, compounded the problem, with the usual 
electricity imports from Syria disrupted (Bouri and El-Assad, 2016) and the influx of thousands of Syrian refugees escaping the violence, which increased electricity demand. All these factors contribute to perennial power outages and load shedding that have impacted many communities in Lebanon since the early 1990s (Bouri and El-Assad, 2016), and have worsened since 2011. The power outages have become normalised and their effects integrated into the rhythm of everyday life in Lebanon (Abi Ghanem, 2018). However, the power outages do not affect everyone in the same way: communities in metropolitan Beirut (the capital) have lived with a schedule of between three and four hours of outage per day, whilst those in the suburbs and the rest of the country endure around six to eight hours of outage daily. In order to meet their electricity needs, the vast majority of people came to rely on an informal network of electricity provision, which gradually grew as a result of this shortage (Abi Ghanem, 2018; Bouri and El-Assad, 2016). The informal system provides electricity to households to cover most outages. At a considerable cost, they not only exacerbate the economic burden and the energy poverty of many households, but also worsen urban air pollution since they are based on diesel generators and located within urban areas (Shihadeh et al., 2013).

As mentioned before, the electricity situation in Lebanon is presented here to make a case for engaging with assemblage theory when exploring energy for development. In the last decade, pathways and plans have been developed for the energy sector in the country, emphasising the need for a reliable infrastructure in order to drive much-needed growth and development (Abosedra et al., 2009). The 2010 Energy Programme (Bassil, 2010) promised administrative and legal reforms, including mechanisms for privatising supply and liberalising the energy market, establishing a regulatory body and investing in renewable energy technologies (RETs). From the plan, a National Renewable Action Plan has been developed and two phases for a National Energy Efficiency Action Plan have been implemented (Jouni et al., 2016). However, the overall reforms and projects outlined in the 2010 Energy Programme are yet to be implemented, owing to political and financial impediments in the country (UN-ESCWA, 2017).

In principle, scrutiny of these plans reveals the extent of the investment and financing needed, and the considerable legal and institutional reform required to bring about the desired change (Machnouk et al., 2019). What can be gleaned from overviewing these documents are the debates on the viability of different approaches and their extent, such as the liberalisation of the energy market to allow new entrants to generate and sell electricity. The expansive list of technological options belies socio-economic and local structures that can inhibit uptake and deepen the energy divide. From a sociological lens, one insight that can be elicited is the notion of energy services centred on the "modern infrastructure ideal" (Graham and Marvin, 2001), and one can trace this project in Lebanon as beginning with the large-scale investments in water and hydroelectric energy from the 1960s (Abd El-Al, 2018). Building on the legacy of the Litani River project (consisting of a large irrigation system and several hydroelectric power plants), the new Energy Programme for Lebanon continues to be dominated by a centralised market-led and state-regulated energy system based on investment in 
large water and energy projects including dams, additional thermal power plants and large-scale PV farms (LCEC, 2016). Further assessment of these plans is beyond the scope of this chapter; suffice to say that insofar as national-level strategy is concerned, an idealised large-scale infrastructure for electricity provision remains the overriding vision.

In practice, the aforementioned RET plans have succeeded in developing a small part of Lebanon's energy sector towards renewable sources (c.f. Moore and Collins, 2020). The extensive uptake of comprehensive reforms, however, is impeded by the political system (Obeid, 2020) and therefore a considerable sustainable energy transition driven by large-scale investment is unlikely given the political instability in the country and the deficit-ridden EDL (UN-ESCWA, 2017). However, given the worsening socio-economic conditions in Lebanon (World Bank, 2019), urgency is required, which cannot wait for political reforms or the legal and regulatory framework (AUB-IFI, 2019), both necessary for largescale sustainable investments in the energy sector (Machnouk et al., 2019). This is evident in that where success is observed, it has been limited to small-scale projects (Moore and Collins, 2020). From this perspective, it can be argued that these plans obfuscate the myriad complexities that have arisen over the years (during and since the civil war), including the socio-political inertia and the reality of informal services and self-generation. In particular, they ignore the notion of hybrid configurations of electricity provision (Verdeil, 2019; Castan Broto et al., 2018) that needs to assimilate the informal network of electricity providers into future energy planning. This is especially the case for Lebanon, given the vested interests that established informal electricity providers have (Rose, 2018; Rosen, 2018 ) and their entrenched power in the country's political system (Moore and Collins, 2020).

This research recognises that the everyday experience of energy access across the different urban areas of Lebanon - their noisy and polluting generators, the different household appliances and equipment, the intermingling wires, as well as the complicated routines and everyday strategies adopted by people to accommodate power outages - all together make up the infrastructure that serves the electricity needs of the country's inhabitants. It is in delineating these networks and associations that we begin to truly understand the energy challenge: how these energy services come to be and come to shape towns and cities, which nowadays are ever more under pressure to drive forward sustainable energy transitions. By doing so, we acknowledge the services' power and influence over any propensity to transition to a more sustainable energy system and the role they could play in the future of energy provision for Lebanon.

Perspectives from geography and science and technology studies (STS) have, over the years, argued for better-informed and context-based approaches to understanding energy and infrastructure (Furlong, 2011; Graham and McFarlane, 2015; Rutherford and Coutard, 2014). In this chapter, these approaches are used to develop an account of infrastructure with a focus on how electricity services in Lebanon are experienced, explaining how the different logics of access have emerged. Thinking through assemblage (McFarlane and Anderson, 2011), these 
disruptions are used as a point through which to trace the entanglements of the electricity infrastructure. These entanglements cut across political pivot points, economic imaginaries and the socio-technical. Following the wires of Lebanon's networked infrastructure elicits not only the heterogeneity of the system that it is characterised by today, but also sheds light on some elements of its history and, importantly, the emergence of the informal system of provision, which has come to significantly influence people's everyday experience of energy and public services (Abi Ghanem, 2018).

Employing an assemblage lens can enrich not only our understanding of the present situation, but open up various possibilities - potentials - for future energy transitions, where such potentials are not often explicit in development practice. Furthermore, an assemblage perspective highlights the agency of networks and pushes our thinking in relation to infrastructure beyond technological systems that can be acted upon and influenced through policy, and instead recognise how these networks can emerge and grow in unexpected directions. In the case of Lebanon, such divergence is a call to appreciate the complexity of the informal electricity provision and how it shapes everyday life. In doing so, we can begin to question notions of lawful state provision set against the informal generator "mafias", as they are often referred to in the media and by the lawmakers themselves (Mohsen, 2012; Rose, 2018). This chapter argues for the potential of the "coming together" of existing and future actors and networks to realise an inclusive approach, in order to sustainably tackle the energy crisis in the country. For energy transitions, the hope is that this study can point towards fresh theoretical tools that can articulate more inclusive and just energy transitions viable in the near future.

\section{Background}

In parallel to the state-owned electricity infrastructure in Lebanon, self-generation has emerged to supplement the much-needed electricity services for residents and businesses in the country. As mentioned earlier, Lebanon's national electricity supplier, EDL, has failed to provide continuous electricity services, and self-generation emerged as a result, supplying approximately $40 \%$ of electricity consumption in Lebanon (Bouri and El-Assad, 2016). In parallel to the infrastructure development plans that have been put in place in the post-war years to augment electricity generation and fill the supply gap (World Bank, 2008), self-generation in the shape of an informal system of provision expanded duing Lebanon's civil war and since the early 1990s, mainly based on privately owned diesel generators.

Throughout the war years, people with the financial means were able to procure small diesel-powered generators for their homes and small businesses (Awada, 1988) in order to supply a few hours of electricity during the extended power cuts brought about by the fighting. After Lebanon's civil war ended, the informal system of provision evolved and consolidated into privately owned generator services dominated by two forms: (1) local entrepreneurs (Verdeil, 2009) who provide subscription services at the neighbourhood level; and (2) co-owned 
medium to large generators that serve residents of apartment blocks, where a building's residents manage their own diesel generator to service all apartments. Since then, recently built real estate developments have come to include large diesel-based generators to serve the apartments even before they are sold. It remains that the most prevalent source of augmented supply for the majority of residents, particularly medium and lower-income neighbourhoods, are the services provided by the local entrepreneurs, where participating homes have to pay a connection charge as well as the monthly subscription fee in return for five or ten amperes ${ }^{1}$ of electricity supply. These service providers have become increasingly prolific in the last 30 years and prevail in both urban and rural settings (Abi Ghanem, 2018), as fewer households opt to manage their own small diesel generators given the additional effort and costs associated with it. A recent survey reports that $66 \%$ of Lebanon's households rely in some way on diesel generators to fill the power outage gap (UNDP, 2018). The widespread presence of these services - particularly those dotted around urban areas - is a significant contributor to local air pollution (Baayoun et al., 2019), resulting in serious environmental health risks for the urban residents (Shihadeh et al., 2013).

Currently, the privately owned generator-based electricity providers function within an ambiguous legal structure. Over the years, exploitative practices have emerged in light of the increasing demand for subscriptions, such as steep prices per ampere and the monopolising behaviour of several providers in different parts of the country, where it could be that a single private generator service controls all neighbourhood connections. In response, in 2010, the government sought to control the cost of informal providers by decree from the Ministry of Energy and Water $^{2}$ through imposing a monthly subscription tariff enforced by local municipalities on private providers in their jurisdictions (Gabillet, 2010). Despite that, the services remain costly for the average household in Lebanon, which is effectively burdened by two electricity bills: one for the national provider, EDL, at approximately $9.5 \mathrm{US}$ cents per $\mathrm{kWh}$ and another for the private providers, which is on average 45 cents per kWh (Bouri and El-Assad, 2016; Hamdan et al., 2012). This double bill equates to many households (46\%) paying up $8.4 \%$ of their income on electricity services (UNDP, 2018). The services are normalised in the citizen's everyday life and embedded in the cities and towns, where new housing blocks are built with space for a generator and sometimes include pre-agreed deals with neighbourhood generator services (Verdeil, 2016; Abi Ghanem, 2018). This means many homeowners and tenants do not have a choice when it comes to informal electricity supply. Moreover, as lower-income households living outside Beirut suffer longer power outages, they pay more for their subscriptions. Lowerincome households are also less likely to live in developments that offer access to co-owned or internally owned generator services, whereas those who do (middle or high-income households) pay relatively less to augment their electricity supply (Verdeil, 2016).

As such, the energy crisis in Lebanon and its negative socio-environmental impacts make the need for a sustainable energy transition ever more urgent. On the policy level, the Energy Programme proposed by the Ministry of Energy and 
Water (Bassil, 2010) included provision for the development and growth of the renewable energy sector, though this is yet to be fully ratified (UN-ESCWA, 2017). More recently, the procurement of electricity from the two Turkish power ships $^{3}$ (Bouri and El-Assad, 2016) have further increased the country's electricity costs and are indicative of the energy impasse the country faces; its inability to meet local electricity demand beyond augmenting power generation (Bouri and El-Assad, 2016). In parallel to the successive governments' effort to secure energy, Lebanon has succeeded in fulfilling its targets in terms of energy efficiency and renewable energy (El-Khoury, 2016), mostly by pushing for solar thermal heaters. Though limited in scale, recently, licences have been granted for three solar PV farms and one wind farm, which should provide cheaper energy to EDL in the future. Thinking along the multiple scales of electricity in Lebanon, from the increasing financial and environmental burden to policy, informality and the technological impasse, can be daunting. However, by closely examining the failing and disrupted services, we are presented with an opportunity to better understand infrastructures in the context of energy transitions. As networks that do not function seamlessly, they reveal their components and highlight the opportunities for change and improvement that are needed.

To consider further opportunities towards greener and more sustainable systems that constitute not only socio-technical trajectories but a more in-depth examination of the implications for justice and wellbeing, a more nuanced approach is needed and often argued for in the socio-economic literature. For example, Moore and Collins (2020) argue for a place-based and people-centred approach, and call for a strategy that goes beyond the traditional top-down structural reforms and investments often promoted by development agencies. They recommend a decentralised energy system that benefits from "citizen insights" (Moore and Collins, 2020: highlights). These examples can be context-specific and are the product of the spatial arrangements they occupy. One such initiative is the Beirut Solar Map project (Berjawi et al., 2017), which, whilst providing a techno-economic assessment of the potential for rooftop solar PV solutions on the densely urbanised capital, has to grapple with the reality of diesel-based generators (their cost, the level of consumption they provide) and contrast that with the benefits of PV technology. Similarly, a recent assessment of the potential for distributed power generation for Lebanon builds on the current informal dieselbased generator market (ESMAP, 2020). This signals that to truly engage with bottom-up, decentralised and hybrid options for a sustainable energy transition, we need to develop a clearer understanding of the "messy" and dispersed nature of the energy infrastructure.

\section{An assemblage approach for thinking through energy transitions}

Assemblage thinking has benefited energy research in recent years (Kumar et al., 2019), highlighting the heterogeneity and diversity of energy services (Lawhon et al., 2018). Building on concepts of assemblage and networks, the notion of 
heterogenous infrastructure configurations has been put forward as a tool for examining and understanding service provision in a way that moves beyond rigid institutional categorisations (state, private, community), as well as the division of infrastructure as formal and informal. It calls for "comparative thinking about the conditions of possibility for incremental change" (Lawhon et al., 2018, 722). In doing so, it emphasises the need to move away from the technology-focused approach still dominant in explorations of energy transitions, and to instead engage critically with energy in a manner that emphasises the processual and emergent nature of infrastructure (Farias, 2011).

The concept of assemblage (DeLanda, 2016; Deleuze and Parnet, 2007) or assemblage thinking (Farias and Bender, 2011; McFarlane, 2011; McFarlane and Anderson, 2011) is, thus, used here to understand the complex relations between myriad elements of the Lebanese electricity problems, which can be social and material, historical and current. An assemblage is best described as "a multiplicity constituted by heterogeneous terms ... which establishes liaisons, relations between them" (Deleuze and Parnet, 2007, 52). Questions in relation to energy and energy services have benefited from assemblage thinking in recent years, where it has shed light on their heterogeneity and diversity, as well as normative concerns including matters of justice and access (Walker and Day, 2013). The multiplicity of scales and the varying geographies of energy (Bouzarovski and Petrova, 2015, 34) alongside its inconspicuous nature (Shove, 2003) and its entanglements in dispersed practices of consumption and production (van Vliet et al., 2005) that are in constant flux, require thinking about energy holistically.

McFarlane (2011) distinguishes between assemblage as a descriptive term and assemblage as an analytical approach, an orientation. As a tool, this helps in bringing into the analysis the different components of the system of electricity provision in Lebanon. It simply aids in generating tools for understanding the challenges and needs from energy infrastructure and to think of them beyond their technological elements. Crucially, assemblage as an approach when studying infrastructures invites us to view the energy system as an "open whole" (Bennet, 2005, 461) that is continuously emerging in space and time. In this way, we see the different components that an assemblage is composed of change, assemble and reassemble, but nonetheless, altogether the different components give the whole its agency. It is the notion of the agency of the assemblage that is important here, and that helps in moving beyond the analysis of the physical and social-cultural constituents of an infrastructure as a socio-technical system that is simply acted upon.

Luque-Ayala et al. (2016) draw attention to the fact that assemblage thinking explains how power works. When considering the case of Lebanon, where formal and informal providers co-exist and where the burden of that is carried by the people, being attentive to how power relations are embedded, and where and how this power can be challenged, is important. This power is not only held by the different members of the assemblage. In the case of Lebanon, we can begin to trace the power of the informal sector through their embeddedness in the urban built 
environment, and through the socio-economic fabric of the different communities they serve. Their strength and influence can be conceived through those sociomaterial relations (Silver, 2015). As Kumar et al. (2019) argue, paying attention to power makes it possible to explore "how power operates through the push of multiple stakeholders, in multiple sites and through a range of diverse practices" (p. 167).

Examining the electricity infrastructure in the case of Lebanon, we find that an assemblage perspective is not only helpful in establishing the grounding for context-based approaches by tracing the spatiality of the infrastructure, but also eliciting the temporality of energy by helping to unpack the flows that constitute the everyday dynamics of electricity service provision. We do so by exploring the heterogeneity of electricity provision in Lebanon, i.e. the growth of an informal electricity network that holds significant influence and power today, as well as an exploration of the historical moments that led to the rise of nonstate actors' and their interventions in the management and delivery of energy services during the war. As such, this chapter reflects on fieldwork conducted over several research visits to Beirut. The research began with a one-month visit in October 2015 and was followed up with further research trips in November 2016, April 2017 and August 2017. These visits focused on conducting a wide range of interviews with ministry officials, academics and experts, energy consultants, operators of generator services and households. The households interviewed included residents in metropolitan Beirut, the suburbs and peri-urban areas surrounding the capital.

Another visit in April 2018 was dedicated to conducting historical research on electricity infrastructure during the civil war. This relied on newspaper archives: the Lebanese daily newspaper Annahar and the now-defunct daily newspaper Assafir, ${ }^{4}$ as well as historic accounts and biographies of prominent political figures and their contemporaries of the civil war years, declassified reports of the civil war period from government sources and grey literature consisting of policy papers and decrees of the Ministry of Energy and Water. These sources were used to document the different incidents that involved the electricity infrastructure, its services and the use of generators. In addition to the archives, historical research involved interviews with several war veterans, local authority figures active during the civil war years and former EDL engineers involved in electricity service provision during the civil war. As such, combining research into the historical rise of informality in Lebanon as well as how it currently functions can enrich not only our understanding of the present situation, the actual (McFarlane, 2011), but open up the possibility for future energy transitions that are not often laid out in development discourses, in other words, the potential. This thinking raises questions of what a more sustainable (and just) future for cities of the global South can look like (Lawhon et al., 2018). In this way, it should stimulate an "alternative way of thinking, being and organising" for infrastructures (Knox, 2017) that builds on plural forms of energy transitioning involving a wider network of existing and future actors (both formal and informal) to realise fairer and greener energy futures. 


\section{Glimpses into the social history of Lebanon's infrastructure failures}

In this section, the current hybrid nature of energy supply in Lebanon is explained from a situated historical perspective by presenting some integral moments during the civil war when an energy assemblage was visible. As Awada (1988) shows, the civil war brought about resilience measures that secured residents' basic needs during periods of fighting. In doing this research, the belief that, prior to the war, electricity provision was universal and uninterrupted was pervasive amongst those interviewed. However, electrification, which began in the late 1920s initially as a colonially established private company that was nationalised in 1964, was not universal and not always available across the different regions (Abu-Rish, 2015; Kassir, 2003), neither was the level of electricity access sufficient to meet the aspirations of the emerging middle class in the early years of the Lebanese Republic (Abu-Rish, 2014). The subsequent hacks as a form of resilience by the "creative" Lebanese (Moore and Collins, 2020) are not simply a war-time response to electricity shortages, rather a challenge by the marginalised poor to the rooted inequality in access to state services. Infrastructure development in Lebanon has always favoured commercial regions and the capital Beirut (Nagel, 2002), and this is also the case in Lebanon's electricity sector since its inception (Abu-Rish, 2015). Therefore, whilst uneven access to electricity services predates the civil war, the purpose of focusing on these moments (leading up to and during the civil war) is to trace the current entrenchment of informal electricity service provision in the country. In doing so, we avoid the pitfall of simply linking the overall electricity crisis in Lebanon to the civil war alone.

Regarding the civil war, its early stages from 1976 to 1982 involved predominantly Christian right-wing political parties with their associated militias, opposed by several leftist parties allied with the Palestinian Liberation Organisation (PLO), who took refuge in Lebanon in 1973 after being expelled from Jordan. One of the right-wing parties, the Kataeb, developed - alongside their political and paramilitary organisation - civil committees whose remit was to lobby government for reform and community development (Frieha, 2017). These committees were later mobilised to provide basic services in lieu of the national infrastructure services for the neighbourhoods they controlled in East Beirut, particularly when the latter were disrupted during battles. These included health, public works, social services, financial services, information, and education. In their work, they intersected with the provision of water and electricity and early on initiated the distribution of kerosene lighting appliances, candles and oil heaters during winter. Their stated objective of doing so was to preserve the dignity of the Lebanese society during the violent impasse and strengthen the resilience of the residents in these areas.

On the left, the PLO, led by Yasser Arafat, were also strong advocates of "steadfastness", and also provided infrastructure and social services by establishing NGOs and cooperative associations. When, during the war, their supply of electricity (coming from the part of Beirut under the control of the right-wing 
militia) was disconnected, they embarked on a new cable connection to access electricity from Jiyyeh station, a thermal power plant south of Beirut. The work on this cable was barely complete when the first phase of the war ended in autumn 1976. In 1978, the work resumed, connecting Beirut to Jiyyeh station and allowing the PLO to continue from their main headquarters in West Beirut (Awada, 1988). The PLO's electricity hack that year sought not only to respond to the hostility of the Christian right-wing militias, but also to congeal the moral and financial support of the national and international allies of the PLO and to showcase the steadfastness and strength of its followers. This moment portrays how electricity access assembled into a crucial development of the civil war: opening up the system of the "informal" and the illegitimate to take shape and become enmeshed into what it means to survive in the city during these precarious times.

Informal patterns of electricity services were also assembled to reveal a neoliberal imaginary for Lebanon's post-war reconstruction in 1983. Believing the war to be close to conclusion, the Lebanese entrepreneur Rafic Hariri (who would later become the country's prime minister) demonstrated a possible rebirth of the then destroyed Beirut downtown by lighting Ma'arad [Exhibition] Street (Bkassini, 2015). Through his company Libano-Oger (Farshakh, 2006), he was sub-contracted by the Municipality of Beirut to maintain and rehabilitate roads and city infrastructure. Given the destruction brought about by the civil war, most of the work consisted of removal of debris and rubble, and the reopening of roads and streets. ${ }^{5}$ One of the projects that Hariri felt strongly about was the relighting of metropolitan Beirut (Shalak, personal communication, 28 March 2018). Although he began in the central neighbourhoods that were inhabited during the war, the lighting of Ma'arad Street remains salient given its location in downtown Beirut, which was a deserted no-man's land at the time (Nagel, 2002). Temporary connections and transformers were used to light up the street, whilst shops and business were invited to reopen for the day to celebrate the revival. Once again, this moment in the history of the temporary, informal and improvised provision of electricity services shows how this assemblage - although fleeting - materialises that yearning for more peaceful times but, crucially, lays down the contours of a neoliberal future for the city of Beirut, defined by a reconstructed commercial centre and supported by functioning infrastructure.

These three examples illustrate how informal electricity services were assembled as sites for reclaiming state power and identity, enabling resistance to perceived threat, and revitalising development and reconstruction driven by neoliberal market forces. Seen this way, the social history of the conflict and of informality in infrastructure services are intertwined. Even though universal access to electricity was never achieved prior to the start of the civil war in 1976, the intersection of salient moments of informality with pivotal moments of the civil war have produced many of the current dominant meanings of electricity provision, whether focused on the capability and role of the legitimate state in services provisioning or the perceived threat of non-state actors on infrastructure control that fester ethnic divisions. These assemblages have determined the extent of informality in upending formal infrastructures of the state, as well as the depth 
of socio-political and ideological drivers in the country's social milieu today. In these moments, the hybridity of service provision and notions of their legitimacy versus the role of the state become visible.

\section{Heterogenous provision in post-war Lebanon}

As mentioned before, Lebanon's electricity provision is characterised by continuous load shedding and power outages, which vary between different areas. Often, coastal cities and towns receive relatively more electricity than more peripheral regions such as peri-urban or rural areas. Indeed, the spatial disparity in managing and augmenting power supply encounters an intricate topography constituted by who supplies the electricity, by what means and in what contractual capacity (Verdeil, 2016). Another differentiation is the type of diesel generator provision a household has access to. Tracing the origins of diesel generator supply, Awada (1988) reported its widespread use along with kerosene rations for electricity, heating and lighting to the households at the beginning of the civil war. These practices widened and, by the late 80 s and early 90 s, there was a proliferation of individual diesel generators, to the extent that the reliance of homes and business on them was perceived as a form of resilience and considered a viable temporary measure for post-war recovery as outlined by the CIA report from that year (US Directorate of Intelligence, 1983). Today, whilst individual small to medium generators still exist, these are mainly in rural parts of the country where they are mostly used by business owners.

Across the country, the informal network of private electricity providers, driven by local entrepreneurs, pervades. Informal electricity supply is based around large diesel generators with wires pouring out of main inverter boxes to neighbouring residents and businesses. These connections run alongside district level low-voltage distribution networks, where the cables and fuse boxes sit alongside the utility connectors and dangle off the electricity poles on the streets. The informal provider's electricity supply "station" in the neighbourhood houses the switches to each building; congregated there are the owners and their electricians. Across the street, you might find a generator, another in a silencer encasing, wires stretched across walls, weaving their way into homes through doorways and windows. Despite their improvised appearance, these informal networks congeal not only through their physical state and ubiquity across the built environment, but through their function, which is dispersed through affective and socio-material moments. One example is Sahar, who bought a newly built apartment in a block outside the capital. When purchasing on the plan, she was informed of "the private provider. His cables and connections were already in place and for every flat in the building there was a placeholder for the ampere meter and the switch". She explains, "it was up to us whether we wanted to activate that connection, but he's the only provider for his neighbourhood. He won't let anyone else do business on his turf'. This example shows how the informal system, integrated coherently in the built environment and emerging as a "mafia" structure (Mohsen, 2012; Rose, 2018), is assembled. In this example, the pre-installation of the informal wiring provides 


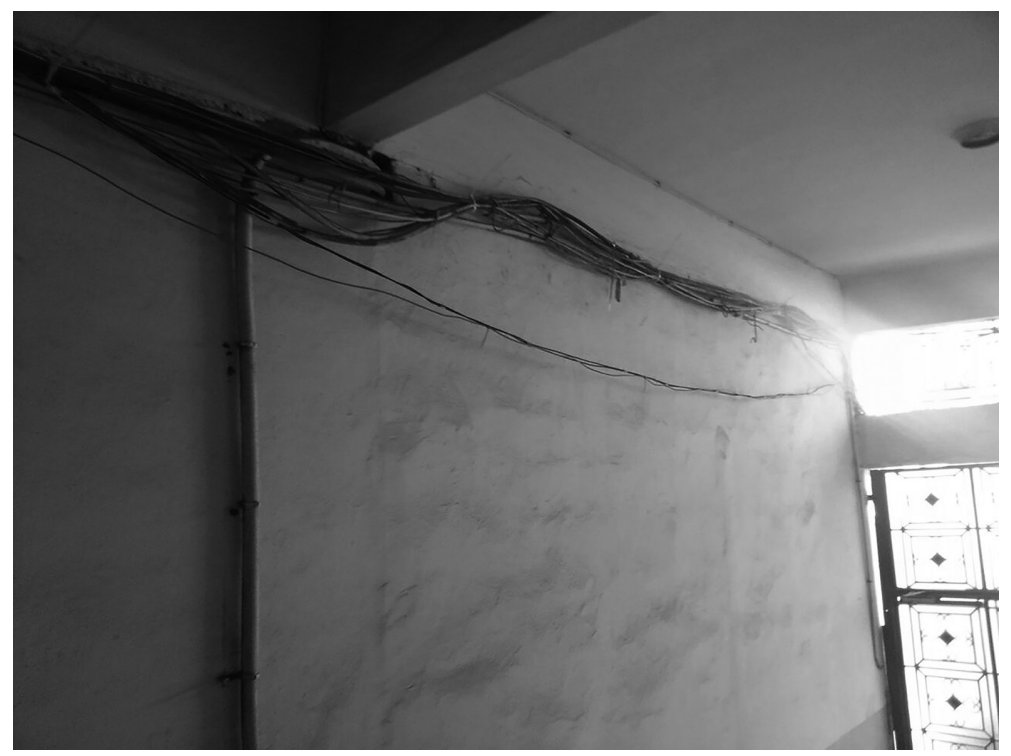

Figure 2.1 Diesel generator wires visible in the foyer of an apartment building in Beirut.

an added level of invisibility, in line with the many dimensions of infrastructure (Leigh-Star, 1999).

As mentioned before, another form of supply is co-ownership, and typically involves residents of an apartment block or building sharing ownership of a relatively larger supply asset that is managed and maintained by the apartment blocks' residents. Costs are shared and the day-to-day service of supply is handled by the building concierge or caretaker. A more recent form of supply follows the contours of the current private providers, but the ownership of the generator and transmission facilities is either community-based organisations or local authorities, and these are often supported financially by political parties. Finally, an oft-cited and less understood (on the practical everyday level) mode of provision is "hacking" or theft of electricity from low-voltage power lines using circuit breakers, with such modes of provision common in poorer and more informal urban settlements, including refugee camps. The purpose of outlining the different informal electricity provision structures is to highlight the intricate relationships that ensue from these supply modes, as well as the differentiated affective and practical outcomes from these arrangements on those who experience and participate in the making of them. For example, different social relations emerge between neighbours in a building who co-own a generator, where economic or financial exchange shapes interactions between them. In a similar way, an informal subscription to a private provider is not purely an economic exchange, as our findings suggest; many subscribers are friends and family whilst the generator owner is also a neighbour and an acquaintance. These contracts are 
held together by not only the wires, but by notions of community, neighbourliness and trust.

After all, the private generator entrepreneurs in many parts of the country are themselves members of these communities. Amongst different providers is competition and cooperation, where factors such as the limits of the network, costs and practical measures precede the securing of a new client. Joseph, a generator owner interviewed in this study, tells me he has turned down subscription requests and recommended a competitor when a customer has a request that he could not fulfil. He added, "he [the competition] doesn't take away my clients, but I don't mind if he does sometimes". The amiable relations are extended in some cases to subscribers, such as Emile, who prefers to do business with Joseph because "he knows him". His wife explains,

we've been with this provider for as long as he's been here, as soon as he got a generator. We've never changed. I don't like to change. Some people here have changed to an "outsider", I mean why? If a person born and bred in your neighbourhood is providing this service, why would we switch to an outsider? I don't like it. I am very principled.

In some way, notions of community and identity are realised through these relationships, and it raises the question of whether active forms of discrimination take place through these informal electricity connections. In other neighbourhoods, the merits of one provider over another are highlighted in how polite the fee collectors are or in the provision of modern automatic switches so that "I don't have to run downstairs to switch the supply over", as Sahar explains. In this instance, the automatic switches ensure the seamlessness of the informal supply arrangement where daily disruptions are avoided or minimised. These, it should be noted, further enhance the invisibility of the informal infrastructure, noted earlier, and its concealment not only within the physical built structures, but also in the routines and rhythms of everyday life.

These heterogenous configurations are also affective. Much like the desired politeness of subscription fee collectors, the power outages and the resulting reliance on informal services bring to the fore reactions and emotions. One notable observation is feelings of abandonment by the state that has "forgotten about its citizens", as Hala tells me; a feeling that overwhelms her as she walks back home through darkened streets lit dimly by the lights from the windows of households "who can afford it". In these daily experiences, the social and political reality of Lebanon are expressed clearly in the darkness and heightened feelings in relation to the role of the state. Theft on the network by using a circuit breaker is less talked about, but Amin - who works as a taxi driver by day - provides his family with electricity by "hacking". He assures me it is safe, adding, "if my parents need light, I will sort it out. Not my brother though, he's not man enough". With Amin, although his theft is out of necessity, the act engenders his role as the good son and underscores his masculinity and power. Though Amin's theft is not unique and parallels historical precedents, it is also a response to pressing needs that he feels can only be provided in this way. 
The examples above show how the informal assemblage wields power, but households can - in some instances - untangle themselves to prevent the burdens and negative impacts of the power outages. Layla will not talk to me about her experience with the private provider in her neighbourhood, "it upsets me", she explains. Instead, she lavished us with more cakes and coffee until her son Salim arrived to show us the UPS system he installed in her attic, as "he knows how it works. He got the idea from working with this IT business. They had the same thing in place", she explains. In her attic, a large UPS system with three lead-acid batteries are carefully mounted onto a steel cradle to automatically rock in place, ensuring the longest battery life (Figure 2.2). This system provides enough electricity to power her fridgefreezer and TV, as well as charging a mobile phone. These are carefully assembled into the network of curtailed household energy consumption, in the timing of washing and ironing, a reconsideration of domestic priorities, and most of all the distress and anxiety that Layla avoids. For her, living outside the capital, her power outages were longer and her bills higher, and by the end of every month, she dreaded "the sight of the private generator's fee collector" walking through her front yard.

By conceptualising the provision of electricity, both formal and informal, as balanced assemblages that are constantly in the making, we avoid unhelpful dichotomies of "state" vs "non-state", "mafia" vs "community". Notions of corruption and theft can be understood in how they are made possible across different scales. The aim of this research was to explore the everyday practices of provisioning electricity services in ways that go beyond these binary labels. On an everyday level, this is necessary if a bottom-up approach to sustainable energy transitions is desired. Accounting for electricity services as material, social and

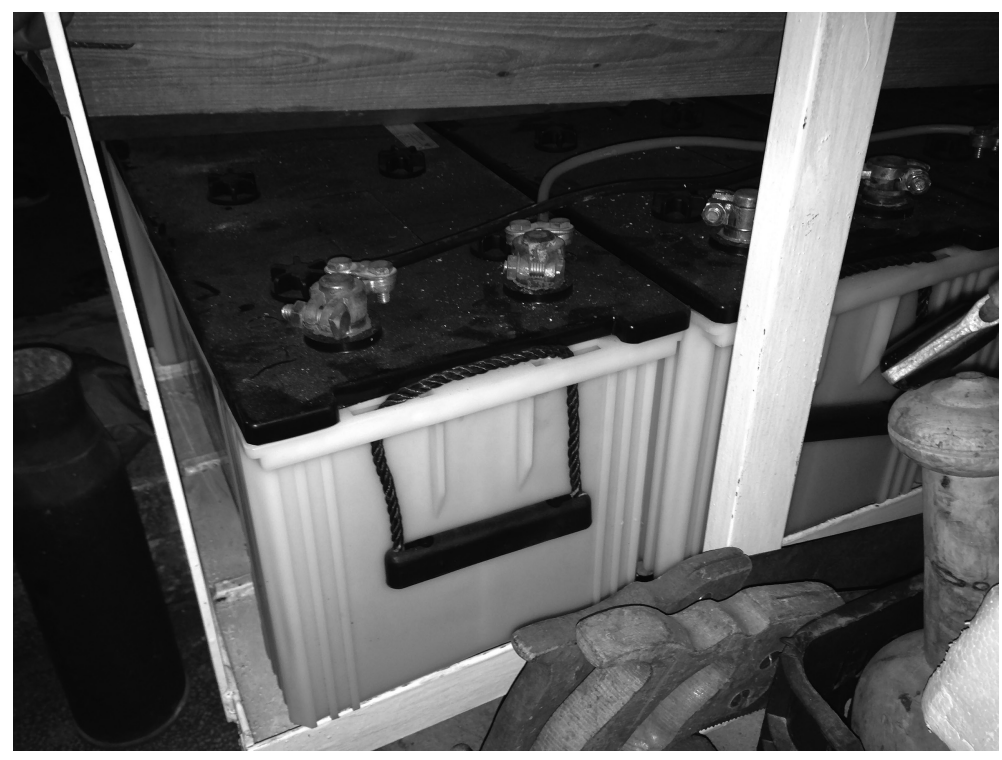

Figure 2.2 Lead-acid batteries mounted on a cradle in the attic of Layla's house. 
political flows, constituent of human and nonhuman elements (Latour, 2005) and emerging as assemblages, opens up the possibility to outline a broader and more inclusive stakeholder engagement at the community level in ways that can be conducive to a greener energy system of provision. By understanding how an individual household can actuate their agency amidst the web of cables, switches and meters, we can then truly build towards a bottom-up approach for a transition to a more equitable and sustainable energy supply. Importantly, this is a call for a pragmatic approach that seeks to engage with all elements of informal supply, rather than the measures that the government has attempted in order to curb the power of the private providers, a recent one being by imposing the installation of metering for the clients of the informal providers (c.f. Rose, 2018).

\section{Conclusion}

In this chapter, the case of Lebanon's ongoing electricity failures was explored through an assemblage perspective. The analysis brought together the lived experience of the informal electricity services and a consideration of the historical moments during the civil war where different formations of informality took shape. The historical contextualisation is not intended as an explanation for the origins of informality. Although it highlights significant moments of its emergence, the assemblage perspective provided a lens through which a study of the experiences of the civil war can be made. Like Braudel (1982, cited in DeLanda, 2016), the aim is to retell these moments by bringing to the fore the agency of diverse entities: the flows of electricity, improvised electrical connections, the city and the streets as well as the people - who are not heroic figures. In this way, the informal electricity assemblages are broadened and their agency is traced both spatially and temporally. Kumar et al. (2019) recommend an assemblage perspective in order to attend to the "socio-technical configurations ... that are continually being assembled, disassembled and reassembled in time and space" (p. 174). Understanding how these processes constituted these assemblages will empower researchers and policy makers of energy in the context of just and urgent transitions to design interventions that are attuned to the existing "ways of doing" electricity and in a way that achieves legitimacy and durability. In so doing, we can begin to challenge the received wisdom of large decentralised infrastructure projects.

In this chapter, a similar view is taken. By employing an assemblage lens, a rich account of the workings of the informal systems of electricity provision was possible, tracing moments in history and accounting for the current realities of energy infrastructure. In the three historical moments, the agency of energy provision highlighted the technology's politics. The historical exploration showed how the assemblage of electricity services took shape through political attempts at resilience, steadfastness and recovery. These moments opened up possibilities of self-provisioning not only as an inevitable consequence to the destruction of infrastructure due to violent infighting, but as a necessity for survival and continuity rooted in national and communitarian beliefs. These connections can be seen in the present day; in the relationships between the providers and the households, 
in the prevalent theft on the network and in the general acceptance of political parties' involvement in generator-based informal provisioning. Accordingly, the challenge of electricity provision is introduced not as a physical network with power plants and pylons that can be acted upon, or fixed. Rather, the multiple ways that the meanings and everyday dynamics of electricity provision drove and have been driven in the past and to this day attest to its continuity, processual nature (Farias, 2011) and agency. In this way, the hybridity of electricity provision through state and non-state actors cannot be ignored.

To address Lebanon's energy crisis, recent governments have sought to price out informal electricity providers (Rose, 2018), but much-needed RET investment plans are yet to be comprehensively realised (LCEC, 2016) and the necessary reforms for the energy sector have not yet been implemented (Obeid, 2020). Government plans such as the Energy Programme (Bassil, 2010) have failed to realise the much-needed system changes and to meet the levels of electricity generation needed. These plans, although ambitious, seek to depoliticise the electricity crisis in the country and neglect the realities of informal electricity services and their rootedness in Lebanon's cities, built environment and everyday life. With the ubiquity of informal provision in mind, an alternative is an approach that is inclusive of the multiplicity of stakeholders that seeks to find commonalities through the various elements of the informal assemblage. By building on local and community-level connections, a plan that incorporates the informal networks of provision and that includes its physical, human and cultural capital, can be an effective strategy to implement distributed renewable energy sources for electricity supply. This approach is arguably more achievable in the context of urgency and can be conducive to prosperity (Moore and Collings, 2020). For example, the connections of private electricity providers can open up the space for implementing microgeneration solutions such as rooftop solar PV. The propensity of householders to shift between different sources of light and electricity enables us to envision energy access that is more diverse, where the heterogeneity and "messiness" can be seen by policy and decision makers as an advantage. By opening up, the challenge is to collaborate with a wider network of actors and change agents where diesel generator owners are invited to participate in cleaner energy opportunities. What should be emphasised is their embeddedness in their communities rather than the oft-cited "mafia" descriptors they are labelled with (Rosen, 2018).

As affective infrastructures (Knox, 2017), notions of historical and current government failures can instead be mobilised into empowering processes of cooperation and collaboration. In better understanding the relational dynamics of energy assemblages as they emerged in the past and as they continue to unfold, we might begin to see an "alternative way of thinking, being and organizing" infrastructures (p. 380). Seen this way, the sites of failure, when explored through the lens of assemblage, are socio-material entanglements that have the potential to produce new energy landscapes that are decentralised, greener and potentially more prosperous (Moore and Collins, 2020). Community-level self-generation is then not an abandonment by the state but an empowering direction towards a sustainable energy policy for the country. 


\section{Dana Abi Ghanem}

Lebanon still faces a considerable challenge when it comes to driving a vision of a greener and more sustainable energy future for its citizens. The ailing physical infrastructure, the mismanagement of natural and financial resources, coupled with a maligned informal system of provision, can seem insurmountable. To the onlooker, they can even suggest that to bring in low-carbon targets is premature. However, the green energy options that the country can exploit should be an integral part of the solution. The decentralisation model is itself not void of questionable political circuits of power, as observed by Verdeil (2019) in the case of local authority-led electricity provision. However, to respond positively to the demands of the people who are suffering energy injustices, a socially and culturally informed approach that engages positively with a multiplicity of actors is argued here as the alternative but necessary orientation to overcome the ecological and political impasse in the country.

\section{Notes}

1 The five and ten amperes are the most common options and indicated in the Lebanese authorities' description of the generator service. The choice depends on the size and income of the household.

2 Decree was issued by the Ministry of Energy and Water (14/10/2010); pursuant to the decision of Council of Ministers No. 2 dated 14/12/2011) to control generator services tariffs through the publishing of monthly permitted tariffs for five amperes and ten amperes respectively.

3 The Turkish power ships, owned by Karadeniz Holding, have since 2013 supplied 25\% of the total electricity demand in Lebanon at a cost of USD 130 million per year for the Lebanese treasury. However, the USD 140 million in unpaid dues suggests that solutions based purely on supply augmentation are unsustainable given the much-needed reforms in the electricity sector that are yet to be implemented.

4 The Annahar newspaper archive was accessed at their headquarters: An-Nahar Bldg., Martyrs' Sq., Marfa' Sector, Beirut, 2014 5401. The archive of Assafir was accessed at the media archives of the American University of Beirut Jafet Library, P.O. Box 11-0236, Riad El-Solh/Beirut 1107 2020, Lebanon.

5 The re-opening of roads and city streets was a common practice after militias closed them off as part of their retaliatory tactics during some of the urban street fighting that was a common occurrence throughout the civil war.

\section{References}

Abd El Al, I. (2018). Historical background on the Litani river. In: Shaban A. and Hamzé M. (eds) The Litani River, Lebanon: An Assessment and Current Challenges. Springer, Cham, pp. 15-31.

Abdelnour, Z. (2003). The corruption behind Lebanon's electricity crisis. Middle East Intelligence Bulletin, 5, pp. 8-9. Available at: https://www.meforum.org/meib/articles /0308_11.htm [Accessed 19 August 2020].

Abi Ghanem, D. (2018) Energy, the city and everyday life: Living with power outages in post-war Lebanon. Energy Research \& Social Science, 36, 36 - 43.

Abosedra, S., Dah, A. and Ghosh, S. (2009). Electricity consumption and economic growth: the case of Lebanon. Applied Energy, 86(4), pp. 429-432. doi:10.1016/j. apenergy.2008.06.011 
Abu-Rish, Z. (2014). On Power Cuts, Protests, and Institutions: A Brief History of Electricity in Beirut (Part One). Jadaliyya. Available at: http://www.jadaliyya.com/ Details/30564/On-Power-Cuts,-Protests,-and-Institutions-A-Brief-History-of-Elect ricity-in-Beirut-Part-One [Accessed 7 October 2016].

Abu-Rish, Z. (2015). Electricity in Early Independence Lebanon, Setting the Agenda. 22nd September [online]. Lebanese Centre for Policy Studies. Available at: https://www.lcp s-lebanon.org/agendaArticle.php?id=55 [Accessed 19 August 2020].

AUB-IFI (2019). Policy Brief: An Emergency Action Plan for Rescuing Lebanon's Energy Sector, Energy Policy and Security Programme. American University of Beirut-Issam Fares Institute Policy Brief, December 2019. Available at: https:// www.aub.edu.lb/ifi/Documents/programs/energy_policy_and_security/documents /20191210_energy_rescue_plan/20191210_energy_rescue_plan.pdf [Accessed 31 August 2020].

Awada, F. (1988). La gestion des services urbains à Beyrouth pendant la guerre: 1975 1985, Vol. 5. Talence : Interurba CNRS-ORSTOM.

Baayoun, A., Itani, W., El-Helou, J., Halabi, L., Medlej, S., El-Malki, M., Moukhaddar, A., Kai Aboujaoude, M., Kabakian, V., Mounajed, H., Mokallad, T., Shihadeh, A., Lakkis, I. and Saliba, N. (2019). Emission inventory of key sources of air pollution in Lebanon. Atmospheric Environment, 215, 116871. doi:10.1016/j. atmosenv.2019.116871

Bassil, G. (2010). Policy Paper for the Electricity Sector. Ministry of Energy and Water, Lebanese Republic.

Bennet, J. (2005). The agency of assemblage and the North American blackout. Public Culture 17(3), pp. 445-465. doi:10.1215/08992363-17-3-445

Berjawi, A.H., Najem, S., Faour, G., Abdallah, C. and Ahmad, A. (2017). Assessing Solar PV's Potential in Lebanon. Issam Fares Institute for Public Policy and International Affairs. American University of Beirut, Beirut, Lebanon. Available at: https://www.aub .edu.lb/ifi/Documents/publications/working_papers/2016-2017/20170808_solar_pvs.p df [Accessed 15 November 2020].

Bkassini, G. (2015). Rafic Hariri: Seerat Amal [Rafic Hariri: A Biography of Hope]. Al-Mustakbal Newspaper (9 February 2015). Available at: https://www.lebanese-forc es.com/2015/02/13/rafik-hariri-hope-biography/ [Accessed 24 August 2020].

Bouri, E. and El-Assad, J. (2016). The Lebanese Electricity Woes: an estimation of the economical costs of power interruptions. Energies, 9, p. 583. doi:10.3390/en9080583.

Bouzarovski, S. and Petrova, S. (2015). A global perspective on domestic energy deprivation: overcoming the energy poverty-fuel poverty binary. Energy Research \& Social Sciences, 10, pp. 31-40. doi:10.1016/j.erss.2015.06.007.

Castan Broto, V., Baptista, I., Kirshner, J., Smith, S. and Neves Alves, S. (2018). Energy justice and sustainability transitions in Mozambique. Applied Energy, 228, pp. 645655. doi:10.1016/j.apenergy.2018.06.057.

Day, R. and Walker, G. (2013). Household energy vulnerability as "assemblage". In: Bickerstaff K., Walker G. and Bulkeley H. (eds) Energy Justice in a Changing Climate: Social Equity Implications of the Energy and Low-Carbon Relationship, Zed Books, London/New York, pp. 14-29.

DeLanda, M. (2016). Assemblage Theory. Edinburgh University Press, Edinburgh.

Deleuze, P. and Parnet, C. (2007). Dialogues II. Columbia University Press, New York.

El Khoury, P. (2016). Beyond 2016. Available at: https://beirutenergyforum.com/p16/Day $\% 203 /$ Session $\% 2012 /$ It's\%20the \%20time\%20to\%20apply\%20law\%20288\%20A\%2 0call\%20to\%20the\%20private\%20sector.pdf [Accessed 15 November 2020]. 


\section{Dana Abi Ghanem}

ESMAP (2020). Distributed Power Generation for Lebanon: Market Assessment and Policy Pathways. (May), World Bank, Washington, DC. https://openknowledge.wor ldbank.org/handle/10986/33788?locale-attribute=es [Accessed 15 November 2020].

Farias, I. (2011). Introduction: decentring the object of urban studies. In: Farías I. and Bender T. (eds) Urban Assemblages: How Actor-Network Theory Changes Urban Studies. Routledge, London, pp. 1-24.

Farias, I. and Bender, T. (2011). Urban Assemblages: How Actor-Network Theory Changes Urban Studies. Routledge, London.

Farshakh, G. (2006). El-Fadel Shalak: Tajrubati ma'a El-Hariri [Al-Fadel Shalak: My days with Hariri]. Arab Scientific Publishers, Beirut.

Fawaz, M. (2009). Neoliberal urbanity and the right to the city: a view from Beirut's periphery. Development and Change, 40(5), pp. 827-852. doi:10.1111/j.14677660.2009.01585.x [Accessed 24 July 2017].

Freiha, G. (2017). Ma'a Bashir: thikrayat wa muthakarat [With Bashir: Memories and a Memoir], 2nd Ed. Entire East Publishing and Distribution, Beirut.

Furlong, K. (2011). Small technologies, big change: rethinking infrastructure through STS and geography. Progress in Human Geography, 34(4), pp. 460-482. doi:10.1177/0309132510380488

Gabillet, P. (2010). Le commerce des abonnements aux générateurs électriques au Liban: Des modes de régulation locaux diversifiés [The trade in rental agreements for electric generators in Lebanon: diversified forms of local regulations]. Géocarrefour, 85(2), pp. 153-163. doi:10.4000/geocarrefour.7861.

Graham, S. and Marvin, S. (2001) Networked Infrastructures, Technological Mobilities and the Urban Condition. Routlege, London.

Graham, S. and McFarlane, C. (2015) Introduction. In: Graham S. and McFarlane C. (eds) Infrastructural Lives: Urban Infrastructure in Context. Routledge, London, pp. 1-14.

Hamdan, H., Ghajar, R. and Chedid, R. (2012). A simulation model for reliability-based appraisal of an energy policy: the case of Lebanon. Energy Policy, 45, pp. 293-303. doi:10.1016/j.enpol.2012.02.034

Jouni, A., Najjar, R. and Mourtada, A. (2016). Evaluation of national energy action plan: the case of the Lebanese NEEAP (2011-2015). IEEE 3rd International Conference on Renewable Energy for Developing Countries (REDEC), Beirut, pp. 1-5. doi:10.1109/ REDEC.2016.7577564. [Accessed 15 November 2020].

Kassir, S. (2003). Beirut [Originally published in French entitled: Histoire de Beyrouth], University of California Press, Oakland, CA.

Knox, H. (2017). Affective Infrastructures and the Political Imaginations. Public Cultures, 29(2), pp. 363-384. doi:10.1215/08992363-3749105

Kumar, A., Ferdous, R., Luque-Ayala, A., McEwan, C., Power, M., Turner, B. and Bulkeley, H. (2019). Solar energy for all? Understanding the successes and shortfalls through a critical comparative assessment of Bangladesh, Brazil, India, Mozambique, Sri Lanka and South Africa. Energy Research \& Social Science, 48(1), pp. 66-176. doi:10.1016/j.erss.2018.10.005.

Latour, B. (2005). Reassembling the Social. Oxford University Press, Oxford.

Lawhon, M., Nilsson, D., Silver, J., Ernstson, H. and Lwasa, S. (2018). Thinking through heterogeneous infrastructure configurations. Urban Studies, 55(4), pp. 720-732. doi:10.1177/0042098017720149.

LCEC (2016). The National Renewable Energy Action Plan for the Republic of Lebanon 2016-2020. Ministry of Enegy and Water, Lebanese Republic. Available at: http:/ 
/lcec.org.lb/Content/uploads/LCECOther/161214021429307 NREAP_DEC14.pdf [Accessed 24 August 2020].

Luque-Ayala, A. and Silver, J. (eds). (2016) Energy, Power and Protest on the Urban Grid: Geographies of the Electric City. Routledge, London.

Machnouk, S., El Houseini, H., Kateb, R. and Stephan, C. (2019). The Energy Regulation Market Review, Edition 8-Lebanon. The law reviews. Available at: https://thelawr eviews.co.uk/edition/the-energy-regulation-and-markets-review-edition-8/1194563/ lebanon [Accessed 24 August 2020].

McFarlane, C. (2011). The city as assemblage: dwelling and urban space. Environment and Planning D: Society and Space, 29(4), pp. 649-671. Available at: http://www.envplan .com/abstract.cgi?id=d4710 [Accessed 17 April 2017].

McFarlane, C. and Anderson, B. (2011). Thinking with assemblage. Area, 43, pp. 162164. doi:10.1111/j.1475-4762.2011.01012.x.

Mohsen, A. (2012). Lebanon's Electricity Mafia. Al-Akhbar Newspaper (June 29 2012). Available at: http://english.ak-akhbar.come/node/9087 [Accessed 24 October 2017].

Moore, H. and Collins, H. (2020). Decentralised renewable energy and prosperity for Lebanon. Energy Policy: 111102. doi:10.1016/j.enpol.2019.111102.

Nagel, C. (2002). Reconstructing space, re-creating memory: sectarian politics and urban development in post-war Beirut. Political Geography, 21(5), pp. 717-725. doi:10.1016/ S0962-6298(02)00017-3.

Obeid, J. (2020). Commentary: Lebanon: The 3-Decade Impossible Power Sector Reforms. Italian Institute for International Political Studies (ISPI), Milan, Italy. Available at: https://www.ispionline.it/en/pubblicazione/lebanon-3-decade-impossible-power-sector -reforms-25377 [Accessed 24 August 2020].

OECD/IEA (2014). IEA Statistics: Energy Imports, Net (Percentage of Energy Use). Available at: https://data.worldbank.org/indicator/EG.IMP.CONS.ZS?locations=LB [Accessed 24 August 2020].

Rose, S. (2018). Lebanese Government Tries to Rein in Billion-Dollar 'Generator Mafias'. The National (November 8 2018). Available at: https://www.thenational.ae/world/ mena/lebanese-government-tries-to-rein-in-billion-dollar-generator-mafias-1.789451 [Accessed 24 August 2020].

Rosen, K. (2018). Inside the Haywire World of Beirut's Electricity Brokers. Wired (August 29 2018). Available at: https://www.wired.com/story/beruit-electricity-brokers/ [Accessed 24 August 2020].

Rutherford, J. and Coutard, O. (2014). Urban energy transitions: places, processes and politics of socio-technical change. Urban Studies, 51(7), pp. 1353-1377. doi:10.1177/0042098013500090.

Shihadeh, A., AlHelou, M., Saliba, N., Jaber, S., Alaeddine, N., Ibrahim, E., Salahieh, Z. and Chiit, M. (2013). Effect of Distributed Electric Power Generation on Household Exposure to Airborne Carcinogens in Beirut. Research Study Report January 2013, Issam Fares Institute Climate Change Programme, American University of Beirut. Available at: https://www.aub.edu.lb/ifi/Documents/events/2012-2013/20130207ifi rsr_cc_effect\%20Diesel.pdf [Accessed 15 October 2015].

Shove, E. (2003). Comfort, Cleanliness and Convenience: The Social Organisation of Normality. Berg, Oxford.

Silver, J. (2015). Disrupted infrastructures: an urban political ecology of interrupted electricity in Accra. International Journal of Urban and Regional Research, 39, pp. 84-1003. doi:10.1111/1468-2427.12317. 
Star, S.L (1999). The ethnography of infrastructure. American Behavioral Scientist, 43, pp. 377-391. doi:10.1177/00027649921955326

UNDP (2018). Energy Efficient Home Appliances: Perspectives from Lebanese Consumers. UNDP-CEDRO, Beirut, Lebanon. Available at: file:///Users/u0033639/Downloads/ CEDRO\%20_\%20Energy\%20Efficient\%20Home\%20Appliances.pdf. [Accessed 15 November 2020].

UN-ESCWA (2017). Case Study on Policy Reforms to Promote Renewable Energy in Lebanon. A paper for the United Nations Development Account project on promoting renewable energy investments for climate change mitigation and sustainable development. United Nations-Economic and Social Commission for Western Asia. Beirut, Lebanon. Available at: file://Users/u0033639/Downloads/policy-reforms-pr omote-renewable-energy-lebanon-english.pdf [Accessed 24 August 2015].

US Directorate of Intelligence (1983). Lebanon: Decaying Infrastructure-An Intelligence Assessment. Central Intelligence Agency, approved for release July 2002. Available at: https://www.cia.gov/library/readingroom/document/cia-rdp84s00927r0002000200 04-7 [Accessed 14 May 2017].

Van Vliet, B., Chappells, H. and Shove, E. (2005). Infrastructures of Consumption: Environmental Innovation in the Utility Industries. Earthscan, London.

Verdeil, E. (2009). Électricité et territoires: un regard sur al crise libanese. Revue Tiers Monde, 2(2), 421-436. doi: 10.3917/rtm.198.0421

Verdeil, E. (2016). Beirut, metropolis of darkness: the politics of urban electricity grids. In: Luque-Ayala A. and Silver J. (eds) Energy, Power and Protest on the Urban Grid: Geographies of the Electric City. Routledge, London, pp. 155-175.

Verdeil, E. (2019). Securitisation of urban electricity supply: a political ecology perspective on the cases of Jordan and Lebanon. In: Yacobi H. and Nassara M. (eds) Routledge Handbook on Middle Eastern Cities. Routledge, London, pp. 246-264. Available at: https://halshs.archives-ouvertes.fr/halshs-02176158/document [Accessed 24 August 2020].

World Bank (1996). Staff Appraisal Report: The Republic of Lebanon-Power Sector Restructuring and Transmission Expansion Project. Available at: http://documents1 .worldbank.org/curated/en/938971468772462743/pdf/multi-page.pdf [Accessed 24 August 2020].

World Bank (2008). Republic of Lebanon, Electricity Sector Public Expenditure Review. Report No. 41421-LB. World Bank, Washington, DC. Available at: http://hdl.handle .net/10986/7990 [Accessed 24 August 2020].

World Bank (2019). Lebanon Electricity Transmission Project P170769. World Bank Publication. Available at: http://documents.worldbank.org/curated/en/2358315628649 51356/text/Concept-Project-Information-Document-PID-Lebanon-Electricity-Tra nsmission-Project-P170769.txt [Accessed 31 August 2020]. 